\title{
Miként kaptak jelzetet az ELTE Egyetemi Könyvtár corvinái?*
}

Ismeretes, hogy az ELTE Egyetemi Könyvtár állományának legjelentősebb bővülése szoros kapcsolatban áll Mária Terézia jezsuita rendet és II. József szerzetesrendeket feloszlató rendelkezéseivel. A XVIII. századi abolíciós intézkedéseket követően összesen mintegy 450 új kézirat, köztük 66 középkori kódex került az ekkor már államosított egyetem könyvtárába. Ehhez az állománygyarapodáshoz mérhetö újabb, minőségi bővülés 1877-ben volt. Ekkor - mint ismeretes - II. Abdülhamid török szultán 35 kódexet, a török fél véleménye szerint kivétel nélkül Magyarországról egykor hadizsákmányként „elhurcolt” corvinákat, ajándékozott a budapesti egyetemistáknak, s ezek örzőhelye az egyetem könyvtára lett. ${ }^{1}$ Miután a „törökországi” kódexeket 1877-ben rövid idöre nyilvános kiállításon mutatták be a Magyar Nemzeti Múzeumban, átszállították a könyvtárba. A könyvészeti kutatás nagyra értékelte és fokozott figyelemmel kísérte a kódexek Magyarországra kerülését, „könyvtáraink és könyvészetünk történetének egyik legörvendetesebb eseményeként" értékelte. ${ }^{2}$

A kódexeket a XIX. század második feli magyarországi tudományos élet több jeles szakértője vizsgálta meg, kutathatóságukhoz elengedhe-

* A dolgozat elkészítésére több körülmény ösztönzött. Ezek közül az egyik, hogy az Egyetemi Könyvtárban őrzött kódexek kutatása még közel sem nem fejeződött be, esetleges „újabb” corvinák „felismerése” feltételesen még várható. Vö. pl. Mikó Árpád, Az Egyetemi Könyvtár Dante-kódexének (Cod. Ital. 1.) eredeti kötéséről. Henszlmann Imre kiadatlan feljegyzése. $=$ Művészettörténeti Értesítő, 63. évf. (2014.) 2. sz. 397-399. p. Másrészt a legutóbbi időkig még szakkutatók is eltévesztik, melyek az Egyetemi Könyvtárban őrzött corvinák jelzetei. Vö. pl. Madas Edit: A Corvina újkori története Magyarországon. = A holló jegyében. Fejezetek a Corvinák történetéből. Szerk. Monok István. Budapest, Corvina Kiadó - OSzK, 2004, 64-81. p., itt: 75, 25. jegyzet - e jegyzet szerint az Egyetemi Könyvtárban a corvinák jelzetei „Cod. Lat. 1-től 14-ig”. De a jelzetsor nem ez! A corvinák jelzetei a könyvtárban: Cod. Lat. 1-13, 31.

${ }^{1}$ Knapp Éva: A,,törökországi” kódexek a budapesti Egyetemi Könyvtárban. = Erödi Béla: Csok Jasa! A török küldöttség látogatásának emlékkönyve. Budapest, Akadémiai Kiadó - Magyar-Török Baráti Társaság. 2001. 119-132. p.

${ }^{2}$ Vö. pl. A Corvinák. = Magyar Könyvszemle, 2. évf. 1877. 2. sz. Vegyes Közlemények, 141. p. 
tetlenül hozzátartozott könyvészeti számbavételük és leírásuk. Ennek elkészítéséhez a francia nyelven készült, török záradékkal ellátott eredeti átadási jegyzőkönyv (Catalogue de la Corviniana) - amit nagy becsben tart és őriz az ELTE Egyetemi Könyvtár (a J 256 jelzeten) - mindössze szerény alapot jelentett. Ebbe a jegyzőkönyvbe ugyanis csupán a kódexek azonosításához szükséges minimális adatok kerültek bele, így a szerzők neve rövid névalakban (például „Nr. 14. Cicero”; vagy „Nr. 24. Tacitus”), a kézirat tartalmának megjelölése (például „Nr. 28. Livre religieux”), esetleg a szerző és a mü együttes megnevezése (például „Nr. 30. Dante, comedia divina”; vagy „Nr. 35. Cicero in Verrem”). A kódexekhez rendelt, minden bizonnyal esetleges átadási sorszám a könyvészeti feldolgozás során megváltozott.

A katalogizálás feladatát elsőként Csontosi János végezte el 1877-ben. A Magyar Könyvszemlében megjelent, bőséges megjegyzésekkel kísért bibliográfia önálló kiadványként, mint különnyomat is hozzáférhetővé vált $A$ Konstantinápolyból érkezett Corvinák bibliographiai ismertetése címen. A kódexek „mütörténeti” leírásában Pulszky Károly nyújtott segítséget. Csontosi a 35 kódex corvina-jellegét - amint azt tanulmányának címe is jelzi - nem kérdőjelezte meg, viszont a kéziratokat három részre osztotta. A felosztás határozottan utal arra, hogy a szakemberek már 1877-ben felismerték, hogy a kódexeknek valószínüleg csupán egy része származhat Hunyadi Mátyás híres könyvtárából. Csontosi szerint az első csoportba tartoznak a „kétségtelen Corvinák, melyek Mátyás király egyenes megrendelésére írattak és a czímlapon az ő czímerét viselik", a másodikba azok, melyeknél a „kiállítási jelleg vagy egyéb körülmény valószínűvé teszik, hogy Mátyás király könyvtárából származnak", végül a harmadikba azok, ,melyek a corvinák characteristiconját nem bírják, a mi azonban nem zárja ki azt, hogy [...] Mátyás király könyvtárába kerültek, vagy a régi magyar királyi könyvtár alkatrészeit képezhették". Csontosit követően, öt részben kiegészítve, Török Árpád XXXV Handschriften. Geschenk des Sultans Abdul Hamid II. (Budapest, Martin Bagó, 1878) címen német nyelven írt a kéziratokról. Csontosi külön utalt a kódexek átköttetésére, a kéziratokba arany festékkel bejegyzett ajándékozási szövegre és a kötetekben fellelhető korábbi könyvtári örzésre utaló jelzetekre török, francia és latin nyelven, valamint arra, hogy csupán a „harmadik csoportba sorozott kéziratokat vágták újra körül”. 
A Csontosi-féle „kétségtelen” tíz corvinán (Cod. Lat. 1-10) kívül további négy „,valószínü” corvinát tekint ma a kutatás - Csapodi Csaba Csapodiné Gárdonyi Klára Bibliotheca Corviniánája (Budapest, 1990) alapján - hiteles corvinának. A négy utóbbiból hiányzik az első levél, így címer sincs ezekben. Ezek a kódexek a következő jellegzetességek miatt corvinák. A Cod. Lat. 11-et jellegzetes, színes festéssel díszített budai aranymetszése (arany alapon zöld, fehér, vörös és kék virágdíszek között a kötet kapitális betüs címe, COMMENTARIACESARIS), a Cod. Lat. 13-at „1487. 17. Augusti In dicionem Regis Mathie per longam obsidionem tandem venit Vyhel imperialis Austrie" bejegyzése miatt tekinti a kutatás corvinának. A Cod. Lat. 13 idézett bejegyzésének készítője magyar személy lehetett, amint erről Bécsújhely magyar névalakja tanúskodik. A Cod. Lat. 12 és 31 jelzetü kódexeket az emendáló, Vitéz János bejegyzései miatt sorolták a Bibliotheca Corviniana állományához.

A „törökországi” kódexek katalogizálása a könyvtár többi kódexének könyvészeti leírásával együtt készült el, mivel 1877 előtt behatóan csak a nyolc magyar nyelvemlék-kódexszel foglalkoztak, szövegkiadás is ezekről készült. Az 1881-ben napvilágot látott katalógusban (A budapesti M. Kir. Egyetemi Könyvtár codexeinek czímjegyzéke - Catalogus Codicum Bibliothecae Universitatis R. Scientiarum Budapestinensis) a „törökországi” kódexek („Codices a Turcarum imperatore dono dati”) - nyelvüktől függetlenül - kapták meg a Cod. 1-35 jelzetet. Ez a szignatúra rend az 1961-ben megjelent, Mezey László által készített latin kódexkatalógusban (Codices Latini Medii Aevi Bibliothecae Universitatis Budapestinensis, Budapest, Akadémiai Kiadó, 1961) megváltozott. A „törökországi” kódexek közül az első 32 tétel megtartotta korábbi jelzetét (1881), míg a Cod. 33, 34, 35 jelzésü kódexeket - a kéziratok nyelvének figyelembe vételével - a Cod. Ital. 1, 2, 3 jelzettel látták el, s a 33, 34, 35-ös számot a latin kódexek jelzésére használták fel. Azaz a corvina kódexek jelzete változatlan maradt.

A könyvtár corvinái között a Csontosi-féle „kétségtelenül” hiteles tíz corvina a Cod. Lat. 1-10 jelzetet viseli. Ezek közül több kódex olyan tartalmi és formai jegyeket hordoz, melyek egyedülállóak a ma ismert corvinák között. E sajátosságok mérlegelésével kapták meg egykorúan ezek a kéziratok jelzeteiket. Így például a Cod. Lat. 1 jelzeten örzött Theophrastus-kódex az egyetlen olyan corvina, melyben a scriptor feltüntette, hogy a kódex Firenzében Vespasiano mühelyében készült („Vespasianus librarius florentinus fieri fecit florentiae"). A Cod. Lat. 2-10 ilyen egyértelmü kü- 
lönlegességet nem tartalmaz, ezért ezek a szerzők, illetve a címek alapján betürendbe sorolva kaptak jelzetet.

\begin{tabular}{|l|l|}
\hline Cod. Lat. 2 & Cicero, Marcus Tullius \\
Cod. Lat. 3 & [Pseudo-] Clemes Romanus \\
Cod. Lat. 4 & Curtius Rufus, Quintus \\
Cod. Lat. 5 & Eusebius [Caesariensis] Pamphili \\
Cod. Lat. 6 & Eusebius [Caesariensis] Pamphili \\
Cod. Lat. 7 & Scriptores Historiae Augustae \\
Cod. Lat. 8 & Silius Italicus \\
Cod. Lat. 9 & Tacitus, Publius Cornelius \\
Cod. Lat. 10 & Tertullianus, Quintus Septimius Florens \\
\hline
\end{tabular}

Ugyanakkor az úgynevezett hiteles corvinák szinte mindegyike őriz valami egyéb sajátosságot is. Így a Cod. Lat. 1-, 2-, 3-, 5-, 6-, 7-, 8-, 9-, 10nek színes festéssel díszített budai aranymetszése van. A Cod. Lat. 3 ezen felül tartalmaz egy olyan lapot (fol. 2v), melynek miniálását utólag készítették Budán. Két hiteles corvina eredetileg Vitéz János könyvtárához tartozhatott, mivel ezekben a szövegjavítások tőle származnak (Cod. Lat. 3, 10). Egy kötet Beatrix királyné könyvtárával érkezhetett Budára (Cod. Lat. 4), ezt a Mátyás királyéval nem egyesített címer jelzi. Berkovits Ilona állapította meg (A magyarországi corvinák, Budapest, 1962, 113-115.), hogy a Cod. Lat. 1, 2, 3, 5, 6, 7, 8, 10 Firenzében, a Cod. Lat. 4, 9 Nápolyban készült. Ezek a felsorolt sajátosságok azonban nem váltak jelzetkiadást befolyásoló elemmé.

Az a további négy corvina, melyekből hiányzik az első levél, és így címer sincs bennük, a következő sorrendben kaptak jelzetet. A jellegzetes, színes festéssel díszített budai aranymetszés miatt a Cod. Lat. 11-es jelzetet kapta a Caius Iulius Caesar által írt, saját hadjáratait megörökítő müvek együttese. A Cod. Lat. 12-öt Vitéz János javította, míg a Cod. Lat. 13 Bécsújhely Mátyás király általi elfoglalását tartalmazó bejegyzése miatt kapta a sorrendben következő szignatúrát. A Cod. Lat. 31 jelzetű kódexben a „törökországi” kódexek jelzeteinek kiadása után azonosították az emendáló, Vitéz János bejegyzéseit, s ekkor már nem változtatták meg a jelzet-rendet. 
A kutatás azóta sem ért véget. ${ }^{3}$ Mikó Árpád 2014-ben publikálta Henszlmann Imre Isztambulban készített kiadatlan feljegyzéseit a Dantekódex eredeti kötéséről. E feljegyzéshez egy rajz is tartozik, mely szerint a kódex kötése egy jellegzetes magyarországi kötéstípushoz tartozott, mely valószínüsíti, hogy a kódexet a XV. században Magyarországon örizték - esetleg a királyi könyvtárban lehetett az örzési helye. Azaz a további forrásvizsgálatok - esetleg - lehetővé teszik a könyvtár corvináinak további bővülését is.

\section{Rezümé}

A dolgozat elkészítésére több körülmény ösztönzött. Ezek közül az egyik, hogy az Egyetemi Könyvtárban őrzött kódexek kutatása még közel sem fejeződött be, esetleges „újabb” corvinák „felismerése” feltételesen még várható. Másrészt a legutóbbi időkig még szakkutatók is eltévesztik, melyek az Egyetemi Könyvtárban őrzött corvinák jelzetei. A tanulmány a kutatás jelenlegi helyzete mellett összefoglalja a jelzetadás történetére vonatkozó ismereteket.

\section{How did the 'Corvinae' of the University Library get shelf marks?}

Writing this study was motivated by several circumstances. One of them is that the research of codices treasured in the University Library is still in progress, and discovering any "new" corvina may be expected. On the other hand, until recently even professional researchers miss the notations of the corvinas treasured in the University Library. This study not only summarizes the current state of the research but also the knowledge of number building history.

KNAPP ÉVA tudományos ügyek referense ELTE Egyetemi Könyvtár

${ }^{3}$ Mikó Árpád: Az Egyetemi Könyvtár Dante-kódexének (Cod. Ital. 1.) eredeti kötéséröl. Henszlmann Imre kiadatlan feljegyzése. = Mủvészettörténeti Értesítő, 63. évf. 2014. 2. sz. 397-399. p. 